\title{
The human factor in school dinners
}

\author{
By Florence E. Morkam, School Meals Officer, Surrey County Council, Education \\ Department, County Hall, Kingston-on-Thames
}

I have used the words 'school dinners' in the title of this paper in preference to 'school feeding' for two reasons.

First because I propose to confine my remarks to what takes place at school dinners as provided by the School Meals Service. Secondly I hope that, by avoiding the word 'feeding', I have conveyed that in the School Meals Service we aim to achieve a measure of social training in addition to providing body nourishment.

Looking back at the history of the provision of meals for children at school we find that the biggest developments are linked with periods when this country was at war.

The I906 (Education) Provision of Meals Act (Great Britain Parliament, I906) enabled local education authorities to provide meals free or at half cost up to the limit of a halfpenny rate. This Act was in part the result of public concern expressed at the state of malnutrition found in recruits for the South African war.

In August I9I4 a new Provision of Meals Act (Great Britain Parliament, I9I4) came into force. This Act improved the financial position for local Authorities. It removed the original cost limit and substituted a 50\% Treasury grant towards the cost of providing meals in school. Legislation remained unchanged until I 939 when the meals grant was merged with the percentage grant on all education services, thereby helping the less wealthy authorities.

In 1944 under Section 49 of the Education Act (Great Britain Parliament, I944) the provision of meals became a statutory duty of local authorities.

Before I944, in fact from the Autumn of I938, war conditions created a heavy demand for school dinners. Existing school-dinner arrangements were expanded and a mushroom development of new schemes began. The increased demand for school dinners arose from the exigency of evacuation, the employment of mothers outside the home, the one-session school day and the decision to give priority food rations to schoolchildren through the medium of school dinner.

At the present time the School Meals Service is providing some 600 million dinners yearly and can claim to be the largest catering organization in the country. The Service works on a closely watched financial basis, it has a clearly defined nutritional policy, it is staffed by people more or less trained for the job who for the most part work under good conditions with carefully chosen modern appliances.

\section{Food requirements}

Guidance on the food requirements for school dinners was first given by the Board of Education (I94I). The circular stated that for children over I I years of age 'School dinners should be planned to provide per child

$\begin{array}{ll}\text { Energy value } & \text { I000 Calories. } \\ \text { First class protein } & 20-25 \text { grammes. } \\ \text { Fat in all forms } & 30 \text { grammes,' }\end{array}$


The circular further stated 'such meals will not be cheap, but it is not the cost of the meal but its nutritional value that should be of paramount importance'.

It has always been the policy to look on the school dinner as the child's main meal for the day. In the war years we were acutely conscious that the home diet was likely to be deficient in certain food factors, notably animal protein and vitamin $\mathrm{C}$. To correct this deficiency special allocations of dried milk and dried eggs were made to school kitchens in addition to a priority meat ration, and orange-juice jelly was provided for school use.

A year after food rationing ended the Ministry of Education (1955) issued a circular to supersede that of the Board of Education (I94r). This Circular defined the standard that school dinners should now reach and amended the energy value to $65^{0}-1000 \mathrm{Cal}$. according to the age and sex of the child, the protein to an average of $20 \mathrm{~g}$ protein of animal origin and fat to $25-30 \mathrm{~g}$.

It will be seen therefore that our nutritional target is clearly defined and the standard at which we aim is high. I am not prepared to make any claims for the School Meals Service as a whole but I can say with some confidence that the majority of kitchens in my Authority attain this standard.

\section{Human factors}

The purchase of food to supply the nutritional requirements within the limits of permitted cost is comparatively easy. The difficulty of our task is in turning these foods into meals that will be acceptable to children and eaten by them.

The measure of our success is influenced by three groups of people: (I) the teachers and ancillary helpers who control the children in the dining room, (2) the staff employed in the School Meals Service from the School Meals Organizer through all the grades of supervisors, cooks and assistant cooks to the kitchen assistants who eye potatoes and wash up and (3) the children. I put the child last not because he is least in importance but because his acceptance of the meal is so much influenced by what is said and done by the other two groups.

The teacher. The attitude of the head of a school to the Meal Service and the behaviour of each member of the school staff on dinner duty is in my view the biggest single factor in determining the attitude of the child to the meal. I find that I can form a good judgement of this attitude by examination of the plate waste in the dining room at the end of any meal. Asked if he ate all his school dinner every day a small boy is reported to have replied 'Oh yes but I always ask for smalls if it's something I don't like, we're not allowed to have nothing of something at our school'.

Discipline can be carried too far in relation to clean plates. In a primary school I remarked on the small portions eaten and was told that the Head was strict about clean plates and as the children dared not leave food almost every child asked for 'smalls'. We told the children that in future everyone would be given a small dinner and the helpers took extra food, mostly vegetable, to those who wanted it. In no time all the children were eating a normal helping and the clean-plate rule was still obeyed, 
I should like to pay tribute to all the teachers who often, despite accommodation difficulties, accept the service of school dinners as part of the child's education and who do their best to make meal times social and happy occasions. As an example I cite a village primary school where every child takes dinner every school day. The Head and the two teachers sit at dinner daily with the children, and the food is served by children of 9--io years old. The cook in charge is everybody's friend and no one would offend her by leaving food uneaten on the plate.

In contrast, there are schools where dinner duty is looked on as an imposition to be got through with the minimum of effort and in as short a time as possible. Food is given out like so many pens or books and no one is interested either in the amount which the child consumes or in how he handles the food. In these schools the percentage of children taking meals is below average and the plate waste is invariably high.

Kitchen staff. In 1939 there were few people available for school-meals work who had experience of cooking on a large scale. Cooks with commercial experience were content if the meal looked good. The idea of putting food value into a meal rather than getting profit out of the sale of it was foreign to them. Cooks with domestic experience did not take readily to the use of standard recipes and to the accurate weighing and measuring of ingredients.

The supply of women trained in institutional management has never been sufficient to meet the demands of the School Meals Service. It has been necessary all the time to train staff in service for posts of responsibility as well as in the skills required in kitchen and dining-room work.

The older women found it hard to discard cooking methods learned from their mothers in favour of what were to them newfangled notions. It has taken many years of patient persuasion for example to achieve good cooking and handling of vegetables. Even now I can find kitchen staff who do the right thing for the children and who cook a little for themselves by methods less good nutritionally.

We have taught new cooking techniques and we have endeavoured also to train our women to understand the principles of good nutrition. Happily, kitchen staff on the whole take kindly to organized training and they endeavour to put what they learn into practice, but as one Yorkshire cook remarked as she left a weekend course 'When you've a smoky chimney and a lot of potatoes to do all this about vitamins goes right out of your head'.

The children. What of the children? We constantly remind ourselves that it is not what is put on the plate but what the child digests that matters. We must present him with what he needs in a form that he will eat with enjoyment. His opinion of school dinners must not be judged by the words he uses to describe it. 'I've had an awful dinner but I've had three helpings' is no reason for sacking the cook.

In common with other human beings his appreciation of dinner is influenced by his emotions and by many factors outside the control of the kitchen staff. Anxiety over examinations, excitement at events taking place in school, the desire to get dinner over and carry on with play or other vital interests, overcrowded dining rooms, noise, unsuitable discipline, a feeling of injustice-all these factors influence 
appetite and affect the intake of food. Most children are more critical of texture than of flavour. Tough skinny meat, gristle and excessive fat are reasons for rejecting meat, however fine its flavour. The difference between beef, mutton and lamb is seldom recognized, meat is just meat. Pork and veal particularly at Christmas time are invariably mistaken by the children for chicken or turkey. Lumpy starch thickenings, skin on milk foods, eyes in potatoes, all these are hated.

Children are conservative in their taste and although we go to great lengths to provide variety I am not sure that it is really important except to the self-esteem of the cooks. Two grammar-school boys assured me recently that they would be happy to have stew or roast every day. They also said that they did not feel well-fed unless they had potatoes.

Foods made familiar by home experience, for example sausages and baked beans, are always popular. Fried chipped potatoes may accompany any dish and be greeted with enthusiasm even by the figure-conscious teenage girl who will refuse the boiled variety.

Colour is of tremendous importance, white and light-coloured sauces are not as acceptable as gravy and brown or tomato sauce.

New ideas must be introduced carefully. Custard or jam sauce is expected with steamed pudding. When a good fruit sauce was introduced recently it was rejected by the children; asked why, they answered 'We don't like beetroot with our pudding'.

The eating of raw vegetables and salad with hot as well as cold first-course dishes is a good habit which the School Meals Service can I think claim to have taught. Salad, once the most hated of foods, is now a firm favourite. At a kitchen where coleslaw is always offered as an alternative to boiled cabbage, a cook told me that her son, now working in industry, frequently asked for it as a treat at Sunday dinner.

The kitchen supervisor and her staff are now accepted by the children as part of the pattern of school life. Some appreciative diners come each day to give their views on what they have eaten. It is not uncommon for children to greet the cooks in the street and to ask them to include this or that favourite dish in future menus.

Kitchen windows and open kitchen doors invariably attract a critical audience. On one occasion a cook intent on adding gravy browning to the stew was startled to hear a small voice enquire 'Do you always put syrup of figs in our stew?'

Many examples could be quoted of children who have learned to eat foods at school which they have formerly rejected at home.

Interested mothers frequently ask for recipes from the school menu and not infrequently they return to ask for further advice. The dishes cooked at home had been criticized for not reaching the school standard.

\section{Conclusion}

The production of 600 million meals a year is the result of a very considerable effort on the part of a large number of people. If I can speak for the school-meals staff I think I should say that our best reward is to see the bright face of a well-fed child and to hear him say 'That was a smashing dinner Miss'. 
REFERENCES

Board of Education (1941). Circ. Bd Educ. no. 157 I

Great Britain Parliament (I906). Education (Provision of Meals) Act 1906. London: H.M. Stationery Office.

Great Britain Parliament (Igr4). Education (Provision of Meals) Act 1914. London: H.M. Stationery Office.

Great Britain Parliament (1944), Education Act 1944. London: H.M. Stationery Office.

Ministry of Education (1955). Circ. Minist. Educ. no. 290. London: H.M. Stationery Office.

\title{
Appetites in retirement: the organized feeding of old people
}

\author{
By Denise W. Newman (Honorary Organizing Secretary, Surrey Old People's \\ Welfare Committee), Little Tangley, Wealdway, Caterham, Surrey
}

At the end of a day of papers covering almost the Seven Ages of Man it is fitting that the last of them should deal with the problem of feeding elderly people. Fortunately I am not called upon to give a scientific treatise on the part played by nutrition in the ageing processes because our knowledge is lamentably small. It is, however, as important to assess the effect of growing old, with all its implications, on the individual's attitude to feeding, which can be done a little more readily.

The feeding of old people has not hitherto been a community responsibility as a specialized activity. The old Poor Law Institutions were the only places where the aged would be found in any numbers, and here they were accorded no separate consideration but were fed in the same way and by the same standards as any other inmates. Tojudge by the figures in the late Professor Drummond's book The Englishman's Food, recently revised by Dorothy Hollingsworth (Drummond \& Wilbraham, I957), they were not so badly off nutritionally even if their dietary regime owed little to inspiration. However, in view of the present-day population trends which give an estimated figure for the 1980's of one person in five being over pensionable age, the subject of this paper is timely.

If we compare this section of the community with others considered in this Symposium a major characteristic emerges. This group is relatively static. The child grows and learns, the hospital patient in the main recovers, the factory and service groups present an age range, but the old merely get older with an aggravation of those difficulties inherent in the condition. I am defining here, of course, those old people who are having to exhibit some degree of dependance on community help, not those who are still living an active life. It might be useful to outline some of the features which characterize the group and which have a bearing on the part played by food and catering. 